Article

\title{
New Insights into Ion Adsorption Type Rare-Earths Mining-Bacterial Adsorption of Yttrium Integrated with Ammonia Nitrogen Removal by a Fungus
}

\author{
Weiying Wang *, Yanqiong $\mathrm{Xu}$, Riming Yan and Zhibin Zhang
}

Citation: Wang, W.; Xu, Y.; Yan, R.; Zhang, Z. New Insights into Ion Adsorption Type Rare-Earths Mining-Bacterial Adsorption of Yttrium Integrated with Ammonia Nitrogen Removal by a Fungus. Sustainability 2021, 13, 9460. https:// doi.org/10.3390/su13169460

Academic Editor: Adam Smoliński

Received: 30 July 2021

Accepted: 21 August 2021

Published: 23 August 2021

Publisher's Note: MDPI stays neutral with regard to jurisdictional claims in published maps and institutional affiliations.

Copyright: (c) 2021 by the authors. Licensee MDPI, Basel, Switzerland. This article is an open access article distributed under the terms and conditions of the Creative Commons Attribution (CC BY) license (https:// creativecommons.org/licenses/by/ $4.0 /)$.
Key Laboratory of Protection and Utilization of Subtropical Plant Resources of Jiangxi Province, College of Life Sciences, Jiangxi Normal University, Nanchang 330022, China; yanqiongxu0729@163.com (Y.X.); rimingyan@163.com (R.Y.); zzbbio@jxnu.edu.cn (Z.Z.)

* Correspondence: wwy@jxnu.edu.cn

\begin{abstract}
Ion adsorption-type heavy rare earths found in southern China are important ore resources, whose yttrium(Y)-group rare-earth elements account for $90 \%$ of the total mass of rare earths known on the planet. At present, ammonia-nitrogen wastewater from extraction of rare earths pose threats to the environment. A bacterial strain (Bacillus sp. ZD 1) isolated from the "Foot Cave" mining area was used for adsorption of $\mathrm{Y}^{3+}$. Its adsorption capacity reached $428 \mu \mathrm{mol} / \mathrm{g}$ when the initial concentration of $\mathrm{Y}^{3+}$ was $1.13 \mathrm{mM}$. Moreover, $50 \mathrm{mg}$ of Bacillus sp. ZD 1 (converted to dry mass) could completely adsorb $\mathrm{Y}^{3+}$ in the mother solution of mixed rare earths from the rare-earth mining area. Ammonia nitrogen in the remaining solution after adsorption was removed through denitrification using a fungus named Galactomyces sp. ZD 27. The final concentration of ammonia nitrogen in wastewater was lower than Indirect Emission Standard of Pollutants for Rare-earth Industry (GB 26451-2011). Furthermore, the resulting fungal cells of Galactomyces sp. ZD 27 could be used to produce single cell proteins, whose content accounted for $70.75 \%$ of the dry mass of cells. This study offers a new idea for integrated environmentally-friendly extraction and ecological restoration of the mining area in southern China.
\end{abstract}

Keywords: rare-earth yttrium ion; biosorption; removal of ammonia-nitrogen

\section{Introduction}

Rare-earth elements, collectively referring to a total of 17 elements including 15 lanthanide elements, together with yttrium (Y) and scandium in the same family, are widely used in many industries, such as national defense, electronics, aerospace, energy, and transportation. Furthermore, they are strategic resources used to promote the upgrading of national strategic emerging industries and maintain national resources and economic security [1]. China benefits from large rare-earth reserves and supplies the vast majority of rare-earth resources on global markets [2]. At present, the "Foot Cave" deposit of heavy rare-earths in Longnan County, Ganzhou City, Jiangxi Province (which is the largest ion adsorption-type heavy rare earth deposit in China with an area of about $40 \mathrm{~km}^{2}$ ) is a main production area of raw materials for heavy rare-earths in China. Rare-earth ions in this mining area are mainly adsorbed on the surface of clay minerals, such as kaolinite, halloysite, and mica. Y-group rare-earth elements account for the majority thereof, $\sum \mathrm{Y}_{2} \mathrm{O}_{3} / \sum \mathrm{TR}_{2} \mathrm{O}_{3}$ is greater than or equal to $90 \%$ [3]. Five rare-earth elements including yttrium, terbium, dysprosium, europium, and neodymium are regarded as the most important rare-earth metals in the USA due to their vital roles in clean energy technology applications $[4,5]$ and a huge market demand leads to the prosperity in mining of Y-rich rare-earth ores. Wells for fluid injection are arranged on the mountain surface, in which ammonium sulphate solution is injected into the ore body to serve as the leaching agent. Based on this, ion exchange of rare-earth ions adsorbed on the surface of clay minerals 
and ammonium ions occurs, and then the rare-earth ions are collected to a hydrometallurgical workshop through liquid collection engineering. Thereafter, the carbonate rare earth products are obtained through precipitation and enrichment by adding ammonium bicarbonate [6]: however, much ammonia nitrogen is used in the process of ore leaching and purification and it enters soil and water under the influences of rainfall, leading to eutrophication and posing great risks to the environment [7]. Therefore, it is urgent to develop an environmentally-friendly extraction process for ion adsorption-type rare-earth ores, to realize sustainable development.

As a new type of metallurgical technique for processing mineral resources, biomining is widely used in theoretical and applied research into the smelting of multiple metal minerals $[8,9]$, in which recovering metals by microbial adsorption forms the second stage of biomining [10]. Due to their large specific area, small volume, and rapid rate of reproduction, bacteria can adsorb a variety of rare-earth ions [11-14]. Microbial adsorption has great application prospects in the mining and metallurgy of rare-earth metal ions [15]; however, the low adsorption capacity of microorganisms for rare-earth ions results in a low extraction efficiency, which limits its application in rare earth mining, metallurgy, and recovery.

The treatment of ammonia-nitrogen wastewater by biotechnology has become a research focus in recent years [16,17]. The conventional microbial degradation of ammonia nitrogen includes aerobic nitrification by autotrophic microorganisms and denitrification by heterotrophic microorganisms under anaerobic conditions, however, such a denitrification system is difficult to realize in practice due to a low nitrification rate and complicated separation of nitrification and denitrification stages [18]. Recently, a group of microorganisms that can combine heterotrophic nitrification and aerobic denitrification has been studied, which shows potential for application in ammonia nitrogen removal [19]. Heterotrophic nitrification and aerobic denitrification of fungi have attracted broad interest: although fungi usually grow slowly, they have a large biomass and a high degradation efficiency and can adapt to harsh environmental conditions. Fungi were found to be able to remove ammonia nitrogen under different substrate concentrations, which play an increasingly important role in the nitrogen cycle [20,21].

In this study, microorganisms with excellent adsorption capacity for $\mathrm{Y}^{3+}$ were screened from the "Foot Cave" Y-rich rare-earth mining area. To realize the extraction of rare earths, the bacteria were used to adsorb rare-earth ions in mother solution from ore soil leached with ammonium sulphate. The waste liquid after adsorption contained a large amount of ammonia nitrogen and was made into a basal medium suitable for the growth of fungi by adding appropriate nutrient elements after dilution. The capacity of fungi that can remove ammonia nitrogen allows the final ammonia nitrogen in mining wastewater to meet prevailing emissions standards. This study lays a foundation for the application of microorganisms in the mining process of ion adsorption-type rare-earth ores in southern China and provides a new idea for solving problems related to ecological damage and environmental pollution in mining areas.

\section{Materials and Methods}

\subsection{Analysis of Soil Samples in the Mining Area and Rare-Earth Extraction with Ammonium Sulphate}

Soil samples were collected from the "Foot Cave" Y-rich rare-earth mining area in Longnan County, Ganzhou City, Jiangxi Province, China in spring (early April) when conditions were optimal for microbial reproduction. Sample collection and determination of the contents of rare earth elements have been published [15]. The processes and results are outlined here. The ore samples were taken back to the laboratory within $12 \mathrm{~h}$. The samples were divided into two parts: one was placed in a refrigerator at $4{ }^{\circ} \mathrm{C}$ for screening strains; the other was used for analysis of the content of rare-earth elements. The analysis results are shown in Supplementary Material (Supplementary Material Table S1). The results demonstrate that the content of rare-earth elements in topsoil at the non-mined site is significantly higher than those at the mined site or in deep soil and the content of $\mathrm{Y}$, a 
heavy rare-earth element, is hundreds of times higher than that of light rare earths. The reason for this is the particularity of ion-adsorbed rare earth occurrence in southern Jiangxi: the parent rock contains a low rare-earth content, which moves upwards with weathering and the topsoil has a high rare-earth content [3]. Based on the measurement of the content of rare-earth elements in the ore samples, the surface soil at the non-mined site was selected as the rare-earth ore sample for leaching with ammonium sulphate solution to obtain a mother solution of rare-earth ions and was used in a microbial adsorption experiment. According to Chi and Tian [22], the leaching of the ion adsorption-type rare-earth ore in southern Jiangxi Province is suitable given the following conditions: the rare-earth ore was leached for $30 \mathrm{~min}$ at room temperature in 3\% ammonium sulphate solution agitated at $250 \mathrm{rpm}$ on a shaking table and then centrifuged at $8000 \mathrm{rpm}$ to acquire the mother solution of rare-earth ions.

\subsection{Screening of Microorganisms for Adsorbing $Y^{3+}$}

Soil microorganisms were isolated from the soil samples by the spread plate method, thus obtaining 26 strains of bacteria and 13 strains of fungi. To screen microorganisms that could adsorb $\mathrm{Y}^{3+}$, the bacterial and fungal biosorbents were prepared separately. Bacterial cells were obtained through liquid-state fermentation for $24 \mathrm{~h}$ in a Luria-Bertani culture medium, while mycelium was acquired by fermentation for 3 to $5 \mathrm{~d}$ in a Potato-Dextrose Broth medium. The resulting bacteria and fungi were harvested by centrifuge, and then ground into powder after being dried. The $\mathrm{Y}^{3+}$ adsorption of the microbe was conducted as follows: $5 \mathrm{~mL}$ of $0.5 \mathrm{mM} \mathrm{Y} \mathrm{Y}^{3+}$ solution was added into a $10-\mathrm{mL}$ centrifuge tube, the tube was placed in an oscillator (Qilinbeier KB5010, Haimen, China) for balancing for $2 \mathrm{~h}$ after adding microbial adsorbents $(5 \mathrm{mg}$ ) and then centrifuged for $10 \mathrm{~min}$ at $6000 \mathrm{rpm}$ to separate adsorbents from supernatant. The concentrations of $\mathrm{Y}^{3+}$ in the initial solution and remaining solution after adsorption were identified and the amount of $\mathrm{Y}^{3+}$ adsorbed by microbial adsorbents was calculated.

\subsection{Sequencing of the $16 S$ and $5.8 S$ rRNA Genes}

A bacterium (No. 1) and a fungus (No. 27) with the best adsorption effects on $\mathrm{Y}^{3+}$ were selected for identifying microbial species. The universal primers $27 \mathrm{~F}$ ( $5^{\prime}$-AGAGTTTG ATCCTGGCTCAG-3' and 1492R (5'-GGTTACCTTGTTACGACTT-3') of bacteria and universal primers ITS1 (5'-TCCGTAGGTGAACCTGCGG-3') and ITS4 (5'-TCCTCCGCTTA TTGATATGC $-3^{\prime}$ ) of fungi were taken as primers and genomes of the No. 1 bacterium and No. 27 fungus were used as templates. The objective fragment was obtained through polymerase chain reaction (PCR) of Taq DNA polymerase (Takara, RR001q) and the PCR procedure is illustrated as follows: the polymerase underwent 30 cycles at $98{ }^{\circ} \mathrm{C}(5 \mathrm{~min})$, $98^{\circ} \mathrm{C}(10 \mathrm{~s})$ at $57^{\circ} \mathrm{C}(5 \mathrm{~s})$, and $72{ }^{\circ} \mathrm{C}(1 \mathrm{~min})$, then fully extended at $72{ }^{\circ} \mathrm{C}$ for $10 \mathrm{~min}$. The objective fragment was sent to Shanghai Sangon Biotech (Shanghai) Co., Ltd., Shanghai, China, for sequencing. After submitting the objective sequences of No. 1 bacterium and No. 27 fungus to the US National Center for Biotechnology Information (NCBI) for alignment, it was found that they were most similar to Bacillus vallismortis and Galactomyces candidum, with similarities of $99.86 \%$ and $100 \%$. The sequences of bacterial species have been uploaded to the NCBI with the serial numbers of MN508970 and MN509003. Phylogenetic tree of the strains was drawn by MEGA5.0.

\subsection{Adsorption Capacity of No. 1 Bacterium for $Y^{3+}$ and Rare-Earth Adsorption by the Bacterium from Mother Solution of Mixed Rare Earths}

The above experimental results show that No. 1 bacterium has the best adsorption effects on $\mathrm{Y}^{3+}$. Therefore, it was selected as the objective strain to ascertain the adsorption capacity for $\mathrm{Y}^{3+}$ and used as a biosorbent to adsorb rare-earth ions from mother solution of mixed rare earths. A stock solution $(10 \mathrm{mM})$ of $\mathrm{Y}^{3+}$ was prepared and diluted 100, 20, and 10 times to get $\mathrm{Y}^{3+}$ solution with different concentrations for later use. In analysis of adsorption capacity of $\mathrm{Y}^{3+}$ by No. 1 bacterium, the bacterial adsorbent was the dried 
bacterial powder. Bacterial powder $(10 \pm 0.05 \mathrm{mg})$ was weighed and added into a $15-\mathrm{mL}$ clean centrifuge tube. After adding $\mathrm{Y}^{3+}$ solution of different concentrations, the tube was put on the oscillator for balancing for $2 \mathrm{~h}$. The bacterium and supernatant were separated by centrifugation and the concentrations of $\mathrm{Y}^{3+}$ in the solution before and after adsorption were determined. Moreover, the adsorption capacity was calculated. The bacterial sample after adsorption with an initial $\mathrm{Y}^{3+}$ concentration of $1 \mathrm{mM}$ was fixed for at least $4 \mathrm{~h}$ in $2.5 \mathrm{mM}$ glutaraldehyde (containing $1 \mathrm{mM} \mathrm{Y}^{3+}$ ) and then fixed in $1 \%$ osmic acid after rinsing. Furthermore, after embedment in Epon 812 resin and gradient dehydration in acetone, the samples were sliced and the morphology of $\mathrm{Y}^{3+}$ adsorbed by the bacterium was observed by a transmission electron microscope (TEM) (JEM1200, Japan) after staining the ultrathin slices with uranium acetate and lead citrate. The adsorption of No. 1 bacterium for rare-earth ions from the mother solution of mixed rare earths was measured as follows: a bacterial cell suspension with $\mathrm{OD}_{600}=2.8$ was obtained through centrifugation after culturing the bacterium for $24 \mathrm{~h}$ in the LB medium. To determine the cell dry mass per millilitre of the cell suspension, $5 \mathrm{~mL}$ of the bacterial suspension was centrifuged to acquire the bacterial cells, which were then dried, and weighed. The dry mass of cells per millilitre of bacterial suspension was about $5 \mathrm{mg}$. That is, the dry bacterial concentration in the bacterial suspension was approximately $5 \mathrm{mg} / \mathrm{mL}$. The prepared bacterial cell suspensions $(1,3,6$, and $10 \mathrm{~mL})$ were placed into the $10-\mathrm{mL}$ clean centrifuge tubes and then the supernatant was removed by centrifugation for $10 \mathrm{~min}$ at $6000 \mathrm{rpm}$. The mother solution of rare-earth ions $(5 \mathrm{~mL})$ was added into the tubes containing the bacterial cells. Thereafter, the tubes were placed on the oscillators for balancing for $2 \mathrm{~h}$ at room temperature and agitated at $200 \mathrm{rpm}$. Finally, we separated the bacterium from the supernatant by centrifugation for $10 \mathrm{~min}$ at $6000 \mathrm{rpm}$. Ion concentrations in the mother solution of rare-earth ions and remaining solution after adsorption were separately identified.

\subsection{Determination of $Y^{3+}$ Concentration}

The content of rare earths in mineral soil samples was determined by ICP-MS after digestion. The concentrations of $\mathrm{Y}^{3+}$ before and after adsorption when screening microorganisms for absorbing $\mathrm{Y}^{3+}$ were measured by Arsenazo III colorimetric method [23]. The reaction system consists of $1 \mathrm{~mL}$ citric acid/phosphate buffer ( $\mathrm{pH} 2.8$ ), samples of $980 \mu \mathrm{L}$ and $1 \mathrm{mM}$ Arsenazo $(20 \mu \mathrm{L})$. After the samples in the system were mixed evenly, the absorbance at $650 \mathrm{~nm}$ was detected by a spectrophotometer (Youke, Shanghai, China), and the concentration of $\mathrm{Y}^{3+}$ was calculated according to standard curves. The standard solution of $\mathrm{Y}^{3+}$ was prepared into $0,0.5,1,5$, and $10 \mathrm{mM}$ for drawing the standard curves. The contents of ions in the mother solution of mixed rare earths and the remaining solution after adsorption were determined by inductively coupled plasma atomic emission spectroscopy (ICP-AES).

\subsection{The Ability of the Fungus to Degrade Ammonia Nitrogen and Wastewater Treatment}

\subsubsection{The Ability of the Fungus to Degrade Ammonia Nitrogen}

By using ammonium sulphate as the sole nitrogen source, No. 27 fungus was cultured in a minimal salt medium (MSM) to reveal the degradation of ammonia nitrogen. The components $(\mathrm{g} / \mathrm{L})$ of the MSM included $0.9 \mathrm{~g}\left(\mathrm{NH}_{4}\right)_{2} \mathrm{SO}_{4}, 4.8 \mathrm{~g}$ glucose, $0.5 \mathrm{~g} \mathrm{~K} \mathrm{HPO}_{4} \cdot 3 \mathrm{H}_{2} \mathrm{O}$, $0.25 \mathrm{~g} \mathrm{KH}_{2} \mathrm{PO}_{4}, 1 \mathrm{~g} \mathrm{NaCl}, 0.25 \mathrm{~g} \mathrm{MgSO} \cdot 7 \mathrm{H}_{2} \mathrm{O}$, and trace elements (TEs) $1 \mathrm{~mL}$. The required raw materials of TEs (g/L) included $50.6 \mathrm{~g}$ EDTA.2Na, $2.2 \mathrm{~g} \mathrm{ZnSO} \cdot 7 \mathrm{H}_{2} \mathrm{O}, 5.5 \mathrm{~g} \mathrm{CaCl}$, $1.0 \mathrm{MnCl}_{2}, 5.0 \mathrm{~g} \mathrm{FeSO}_{4} \cdot 7 \mathrm{H}_{2} \mathrm{O}, 1.1 \mathrm{~g}$ ammonium molybdate, $1.6 \mathrm{~g} \mathrm{CuSO}_{4}$, and $1.6 \mathrm{~g} \mathrm{CoCl}_{2}$, with a $\mathrm{pH}$ of 6.0 . Seed solution $(1 \mathrm{~mL})$ was added into the MSM for culture for $2 \mathrm{~d}$ at $28^{\circ} \mathrm{C}$ at $150 \mathrm{rpm}$ and the concentrations of ammonia nitrogen and biomass of the fungus were ascertained by sampling at different times. The degradation curve of ammonia nitrogen and growth curve of the fungus were plotted. The concentration of ammonia nitrogen was determined by Nessler's reagent spectrophotometry and the biomass of fungus was determined by measuring the turbidity of bacterial culture at $600 \mathrm{~nm}$. 
Under different concentrations of ammonia nitrogen, the ability of No. 27 fungus to degrade ammonia nitrogen and the growth of the fungus were explored according to the method of Liu et al. [24]. The procedure is as follows: the MSM was used and the concentrations of ammonia nitrogen were set to 400, 800, 1400, 2000, and $2500 \mathrm{mg} / \mathrm{L}$. At $\mathrm{C} / \mathrm{N}=10$, glucose to corresponding concentrations was added, while the other components were not changed. It should be noted that, different volumes of ammonium ion stock solutions (sterilized by $0.22-\mu \mathrm{m}$ filtration membrane) were added to the cooled culture medium to prevent Maillard reaction between ammonia nitrogen and some components in the culture medium at high temperature, thus avoiding interference with the determination of the concentration of ammonia nitrogen. After introducing the seed solution ( $1 \mathrm{~mL})$, the fungus was cultured for $100 \mathrm{~h}$ at $150 \mathrm{rpm}$ at $28^{\circ} \mathrm{C}$. During this period, the samples were taken to measure the concentration of ammonia nitrogen and biomass of the fungus.

\subsubsection{Design of a Uniform Experiment}

High-concentration ammonia nitrogen was contained in the mother solution of mixed rare earths and the concentration of ammonia nitrogen in the residual waste liquid after adsorbing rare-earth ions by the bacterium was about $2200 \mathrm{mg} / \mathrm{L}$. To decrease ammonia nitrogen levels remaining in the waste liquid that reach the prerequisite emissions standard, the original waste liquid was diluted five-fold to reduce the ammonia nitrogen concentration to about $400 \mathrm{mg} / \mathrm{L}$. In this case, the content of the other nutrient elements therein was almost zero. Therefore, the mixed liquid containing glucose, phosphorus source (dipotassium hydrogen phosphate: potassium dihydrogen phosphate $=2: 1), \mathrm{NaCl}(1 \mathrm{~g} / \mathrm{L})$, $\mathrm{MgSO} 4 \cdot 7 \mathrm{H}_{2} \mathrm{O}(0.5 \mathrm{~g} / \mathrm{L})$ and $1 \%$ o trace elements was added to prepare the culture medium that is suitable for microbial growth. To optimize the $\mathrm{C} / \mathrm{N}$ ratio, the initial concentration of ammonia nitrogen and content of phosphorus source in the culture medium minimizes the final concentrations of the remaining ammonia nitrogen, sugar, and phosphorus in the culture solution, a uniform experiment was designed according to the following Table 1. A total of six groups of experiments (three replicates each) were conducted, and the fungus and supernatant were separated through centrifugation after culture for $3 \mathrm{~d}$ at $28{ }^{\circ} \mathrm{C}$. Ammonia nitrogen, nitrate nitrogen, total nitrogen, chemical oxygen demand (COD), and total phosphorus in the supernatant were determined by the distillation-neutralization titration method (HJ 537-2009), phenol disulphonic acid spectrophotometry (GB/T 74801987), alkaline potassium persulphate digestion-UV spectrophotometry (HJ 636-2012), dichromate method (HJ 828-2017), and ammonium molybdate spectrophotometry (GB/T 11893-1989), respectively. Based on the measurement results, an equation was deduced through regression analysis.

Table 1. Uniform design test factor level U6 (63).

\begin{tabular}{cccc}
\hline $\begin{array}{c}\text { Num. of } \\
\text { Experiments }\end{array}$ & $\begin{array}{c}\mathbf{X} \mathbf{1} \\
\text { Concn. of } \mathbf{N H}_{\mathbf{4}}{ }^{+}-\mathbf{N}(\mathbf{m g} / \mathbf{L})\end{array}$ & $\begin{array}{c}\mathbf{X} 2 \\
\mathbf{C} / \mathbf{N}\end{array}$ & $\begin{array}{c}\mathbf{X} \\
\text { Concn. of Phosphorus (mg/L) }\end{array}$ \\
\hline 1 & 50 & 5 & 60 \\
2 & 100 & 20 & 200 \\
3 & 150 & 40 & 40 \\
4 & 200 & 2.5 & 20 \\
5 & 300 & 10 & 80 \\
6 & 400 & 30 & 160 \\
\hline
\end{tabular}

To verify whether the optimized formula can ensure the maximum degradation of ammonia nitrogen, the culture medium was prepared according to the amounts of carbon source, nitrogen source, and phosphorus source in the above formula while keeping other components unchanged. In the medium, No. 27 fungus was inoculated and cultured for $3 \mathrm{~d}$, thereafter, the fungus and supernatant were separated through centrifugation for $10 \mathrm{~min}$ at $8000 \mathrm{rpm}$. The supernatant was used to identify the content of the components, and the fungus was frozen, dried, and weighed to determine the content of single cell 
proteins. The crude protein content in the fungus was obtained according to the method recommended by the national standard (GB5009.5-2016), that is, the crude protein content in the samples was determined by a Kjeldahl nitrogen meter after digestion of fungal cells. The crude protein content in the samples was calculated in accordance with the formula $\mathrm{X}=\frac{\left(\mathrm{V}_{1}-\mathrm{V}_{2}\right) \times \mathrm{C} \times 0.0140}{\mathrm{~m} \times \mathrm{V}_{3} / 100} \times 6.25 \times 100$ Where, $\mathrm{X}$ represents the content $(\mathrm{g} / 100 \mathrm{~g})$ of proteins in the samples; $V_{1}, V_{2}$, and $V_{3}$ denotes the volume $(\mathrm{mL})$ of standard titrant of sulphuric acid or hydrochloric acid consumed by the test solution, the volume $(\mathrm{mL})$ of standard titrant of sulphuric acid or hydrochloric acid consumed by the blank reagent, and the volume $(\mathrm{mL})$ of the adsorbed digested fluid, respectively. $C$ denotes the concentration (mol/L) of standard titration solution and $\mathrm{m}$ is the mass $(\mathrm{g})$ of the sample.

\section{Results and Discussion}

\subsection{Strain Screening}

The results show that 39 strains of microorganisms screened from the rare-earth ore exert different adsorption effects on $\mathrm{Y}^{3+}$, among which No. 1 and No. 27 strains have the best adsorption effects on $\mathrm{Y}^{3+}$ (Figure 1). The morphology of the No. 1 strain on the agar plate is like that of a bacterial colony, while the No. 27 strain presents a fungus-like morphology. By investigating conservation of $16 \mathrm{~S}$ rRNA and 5.8S rRNA sequences, it was found the No. 1 strain belongs to the Bacillus species and is named Bacillus sp. ZD1, while the No. 27 strain is a Galactomyces sp., named Galactomyces sp. ZD27 (Figure 2).

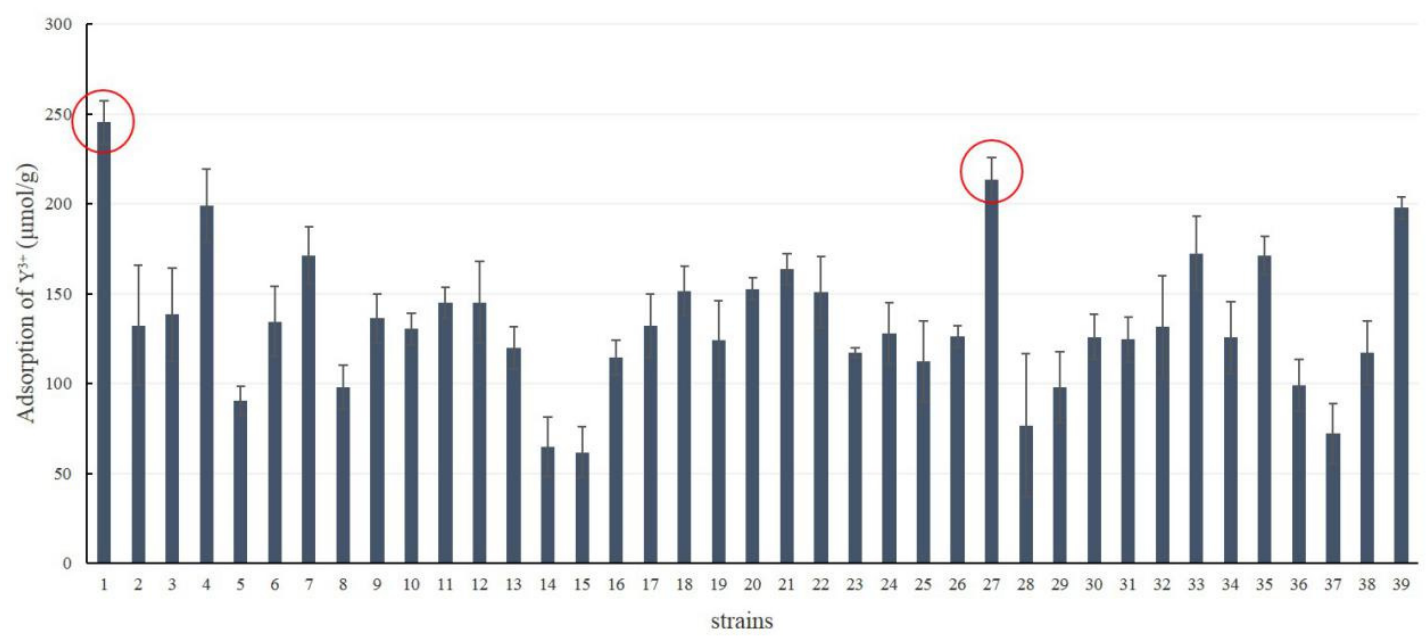

Figure 1. Adsorption effects of 39 strains of microorganisms screened from rare-earth mining area for rare-earth ions $\mathrm{Y}^{3+}$ (Nos 1 to 26 are bacteria, while Nos 27 to 39 are fungi).

\subsection{Adsorption of Bacillus sp. ZD1 for $\mathrm{Y}^{3+}$ at Different Concentrations}

Bacteria can adsorb various rare-earth ions due to characteristics, such as the large specific area, small volume, and rapid rate of reproduction [14,25,26]. Many studies indicated that multiple rare-earth ions are adsorbed based on the biomass of bacteria. For example, Mullen et al. [27] compared and studied the adsorption of several types of bacteria (Bacillus cereus, B. subtilis, Escherichia coli, and Pseudomonas aeruginosa) for a variety of metal ions. The results show that bacteria in a $1 \mathrm{mM} \mathrm{La}^{3+}$ system can adsorb $27 \%$ $\mathrm{La}^{3+}$ on average [11]. Texier et al. [28] found that $P$. aeruginosa adsorbed $\mathrm{La}^{3+}, \mathrm{Eu}^{3+}$, and $\mathrm{Yb}^{3+}$ by multilayer adsorption, with the maximum adsorption capacities of 397, 290, and $326 \mu \mathrm{mol} / \mathrm{g}$, respectively. Under different initial concentrations in this study, adsorption capacities of Bacillus sp. ZD 1 for $\mathrm{Y}^{3+}$ are different (Table 2). When the initial concentrations are $0.09,0.48$, and $1.13 \mathrm{mM}$, the adsorption capacities of bacteria per gram for $\mathrm{Y}^{3+}$ are 90 , 299 , and $428 \mu \mathrm{mol}$ and removal percentage are $100 \%, 62 \%$, and $38 \%$. Compared with the adsorptions of rare-earth ions by microbes, the adsorption capacity of Bacillus sp. ZD 1 for 
$\mathrm{Y}^{3+}$ is higher under the same initial concentration, indicating that the bacterium could be used to adsorb rare-earth ions.

A
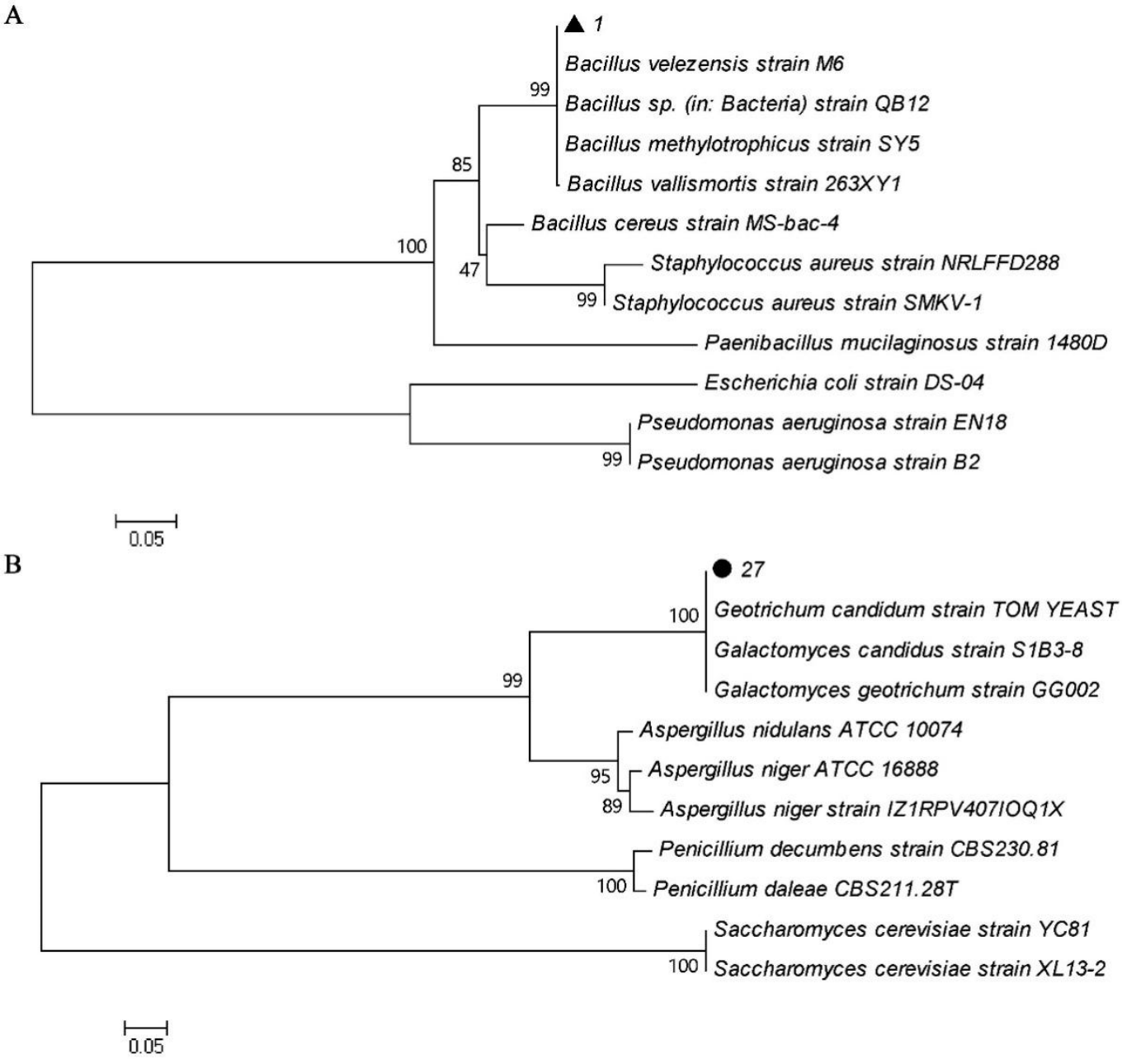

Figure 2. Evolutionary relationships of taxa (1: solid triangle, 27: solid circle). (A) strain No. 1. (B) strain No. 27. The evolutionary history was inferred using the neighbor-joining method; evolutionary analyses were conducted using MEGA5.

Table 2. Adsorption capacity and removal percentage of $\mathrm{Y}^{3+}$ by Bacillus sp. ZD 1 under different initial $\mathrm{Y}^{3+}$ concentrations.

\begin{tabular}{|c|c|c|c|}
\hline & \multicolumn{3}{|c|}{ Sorption $\left(\mu \mathrm{mol} \cdot \mathrm{g}^{-1}\right)$ with an Initial Concentration of $\mathrm{Y}^{3+}$} \\
\hline & $0.09 \mathrm{mM}$ & $0.48 \mathrm{mM}$ & $1.13 \mathrm{mM}$ \\
\hline adsorption capacity & $90( \pm 13)$ & $299( \pm 30)$ & $428( \pm 81)$ \\
\hline removal percentage & $100 \%$ & $62 \%$ & $38 \%$ \\
\hline
\end{tabular}

Microorganisms are the earliest and most common life forms that make contact with metal ions in the natural environment and biosorption is the most direct mode of contact between them. Biosorption is an independent metabolic process occurring on the cell walls of organisms or biomass. For example, algae, yeast, bacteria, and their biomass are used to adsorb metal cations [29-31], and metal ions are adsorbed by functional groups (amino, carboxyl, phosphate, etc.) on the surface of microorganisms. Adsorption mechanisms include electrostatic interaction [32,33], ion exchange [34], surface chelation [35], redox [32], and precipitation [36,37]. The surface adsorption of microorganisms for metal ions is usually a passive process that does not depend on energy metabolism and reaches equilibrium quickly. The adsorption capacity usually accounts for most of the metal accumulated by microorganisms [38,39]). Based on the analysis using the TEM combined with the electron 
energy spectrometer, it is found that the adsorption for $\mathrm{Y}^{3+}$ by Bacillus sp. ZD 1 is extracellular when the adsorption reaches equilibrium at $2 \mathrm{~h}$ and $\mathrm{Y}^{3+}$ is adsorbed on the surface of bacterial cells, as if in clumps of villi (Figure 3 and Supplementary Material Figure S1). $\mathrm{Y}^{3+}$ may be adsorbed by functional groups (amino, carboxyl, phosphate, etc.) on the surface of Bacillus sp. ZD 1.

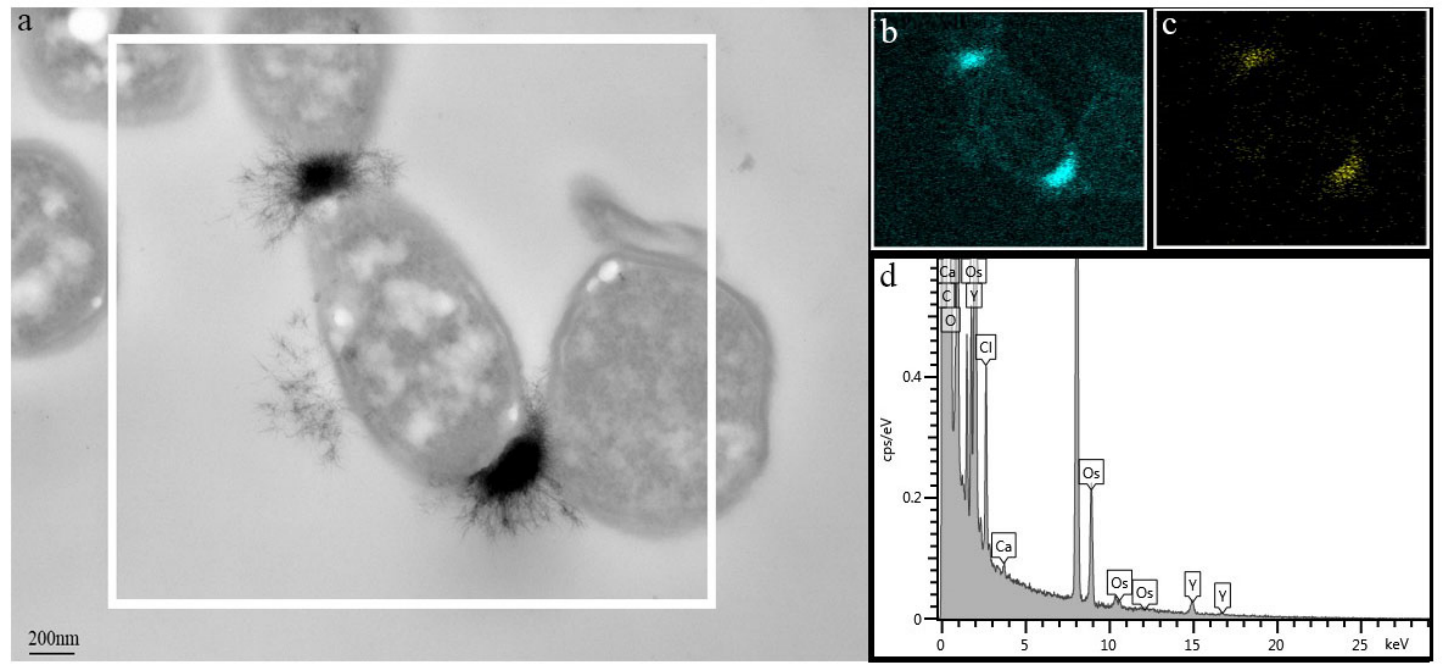

Figure 3. Transmission electron micrograph of Bacillus sp. ZD1 cells equilibrated with $1 \mathrm{mM} \mathrm{Y}^{3+}$. (a) Precipitates are villous deposits around the cell. Bar, $200 \mathrm{~nm}$. (b,c) show element maps of O (green) and Y (yellow). (d) Scans of the white rectangular box in a.

\subsection{Prepared Mother Solution of Mixed Rare-Earth Ions and Bacterial Adsorption for Rare-Earth Ions}

The total content of rare earth in soil samples is $2091.42 \mathrm{mg} / \mathrm{kg}$ (Sc and Po are not included); the total rare earth content in soil leaching solution after treatment with ammonium sulphate is $1073.95 \mathrm{mg} / \mathrm{kg}$ (Supplementary Material Table S2) This suggests that $51 \%$ of the total rare-earth elements in the rare-earth ore can be desorbed into the leaching solution by using 3\% ammonium sulphate solution to leach the rare-earth ore. The leaching liquor resulting from the use of ammonium sulphate is the mother solution of mixed rare-earth ions. The analysis results of ICP-AES show that the content of heavy rare earths in the leached mother solution is slightly higher than that of light rare earths (Supplementary Material Table S2). It is worth mentioning that $\mathrm{Y}$ accounts for $67 \%$ of the mother solution of mixed rare-earth ions and its leaching percentage reaches $51 \%$. By adsorbing rare-earth ions in the mother solution of rare-earth ions by Bacillus sp. ZD 1 cells of different concentrations, the results show that bacterial adsorbent of $5 \mathrm{mg}$ can adsorb $17.42 \%$ of $\mathrm{Y}^{3+}$, and percentage of adsorption of bacterial adsorbents $(15,30$, and $50 \mathrm{mg})$ for $\mathrm{Y}^{3+}$ separately reach $31.40 \%, 67.98 \%$, and $99.21 \%$ (Figure 4 ).

The 15th International Conference on Environmental Science and Technology held in Greece in 2017 redefined the meaning of biomining and considered biomining as a bio-metallurgical technology combining bioleaching in the first stage and biosorption in the second stage [10]. A number of biological mining processes rely on the fact that most of the metal ions can be recovered by the following two steps: obtaining the leaching solution containing metal ions through use of the bioleaching technology, then adsorbing metal ions by (micro) biosorption, and finally recovering metal ions by the combustion of the (micro) adsorbent $[40,41]$. The extraction of rare-earth ions in the mother solution of mixed rare earths only involves biosorption. Bacillus sp. ZD1 with strong adsorption ability for $\mathrm{Y}^{3+}$ can be used to adsorb rare-earth ions in the mother solution and rare-earth elements can be recovered through combustion. This lays a foundation for the biological mining technology in the exaction of the rare-earth ore. 


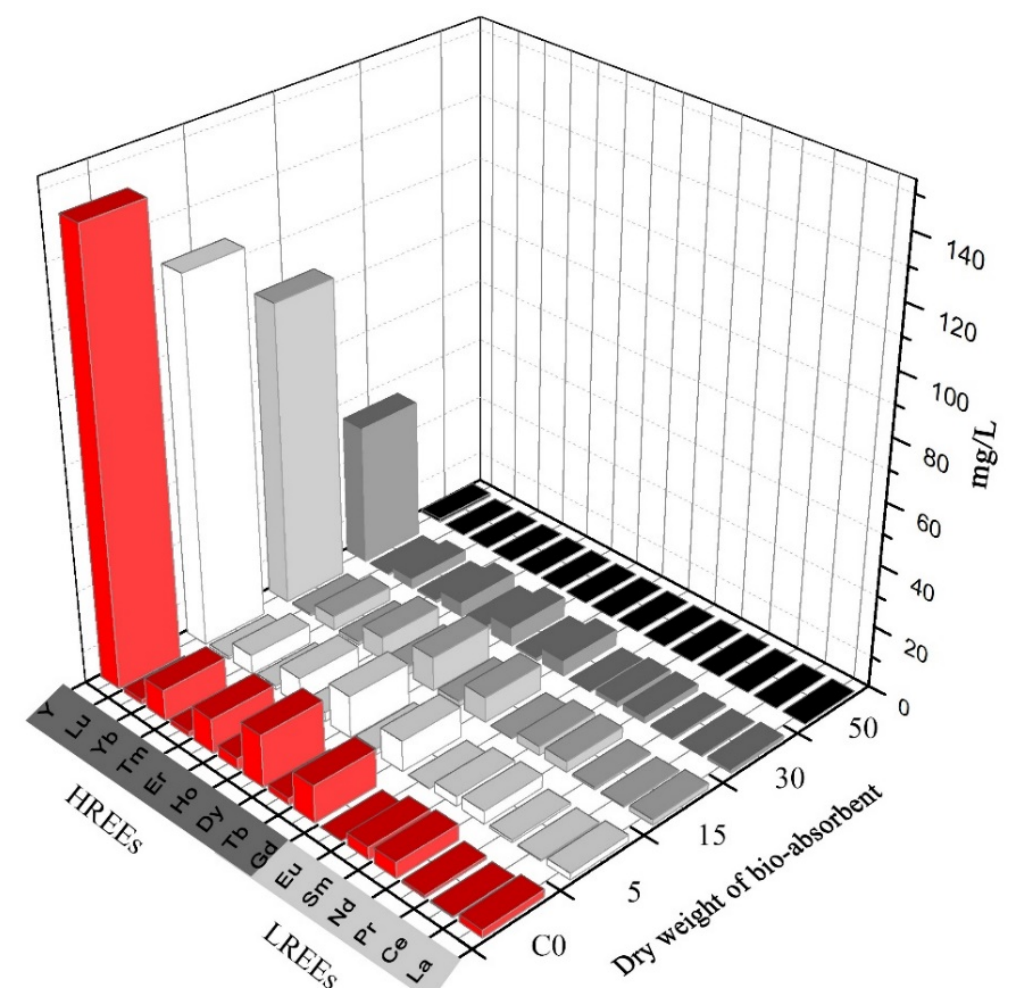

Figure 4. Adsorption of rare-earth ions in mother solution of mixed rare earths by a bacterial adsorbent, Bacillus sp. ZD1.

\subsection{The Removal of Ammonia Nitrogen by Galactomyces sp. ZD27}

Biodegradation is an important process in the field of wastewater treatment. At present, some denitrifying bacteria, such as Pseudomonas [42], Alcaligenes faecalis [43], and Burkholderia [7] have been identified: however, compared with bacteria, filamentous fungi are easier to cultivate and immobilize, especially some fungi which can form mycelial pellets and have good biological properties. A strain of heterotrophic nitrifying fungus that can degrade ammonia nitrogen was isolated from activated sludge in an aeration tank for coking wastewater and was cultured for $3 \mathrm{~d}$ under an initial concentration of ammonia nitrogen of $130 \mathrm{mg} / \mathrm{L}$. Its degradation percentage for ammonia nitrogen is $95.68 \%$ and there is almost no accumulation of nitrite nitrogen and nitrate nitrogen [44]. Liu et al. [24] obtained a strain of fungus Paecilomyces variotii with strong ability to remove ammonia nitrogen isolated from chicken manure compost. When the concentration of ammonia nitrogen is lower than $100 \mathrm{mg} / \mathrm{L}$, the removal percentage for ammonia nitrogen is $100 \%$; as the concentration of ammonia nitrogen exceeds $1100 \mathrm{mg} / \mathrm{L}$, the removal percentage is $40 \%$ and the maximum degradation percentage is $15 \mathrm{mg}-\mathrm{N} / \mathrm{L} / \mathrm{h}$. In this research, when culturing the No. 27 fungus by taking ammonia nitrogen with the concentration of $248 \mathrm{mg} / \mathrm{L}$ as nitrogen source, the adaptive period of the fungus is $6 \mathrm{~h}$, followed by a tendency to rapid growth. At $20 \mathrm{~h}$, a stationary period is reached, and the rate of degradation of ammonia nitrogen is maximized in the logarithmic period. Ammonia nitrogen is almost completely degraded when reaching the stationary period after culturing for $20 \mathrm{~h}$ (Figure 5).

The determination results of the No. 27 fungus in terms of its tolerance to and degradation effects on high-concentration ammonia nitrogen show that the fungus has consistent growth curves under high concentrations of ammonia nitrogen and all densities of the fungus reach $\mathrm{OD}_{600}$ of 1.2 in the stationary period. The results indicate that highconcentration ammonia nitrogen cannot inhibit growth of No. 27 fungus (Figure 6). Under different concentrations of ammonia nitrogen, the rapid degradation process of ammonia nitrogen always occurs in the logarithmic growth period of Geotrichum sp. After entering 
the stationary period, the degradation rate of ammonia nitrogen is very low and remains quasi-constant. The degradation of ammonia nitrogen under different initial concentrations is summarized in Table 3.

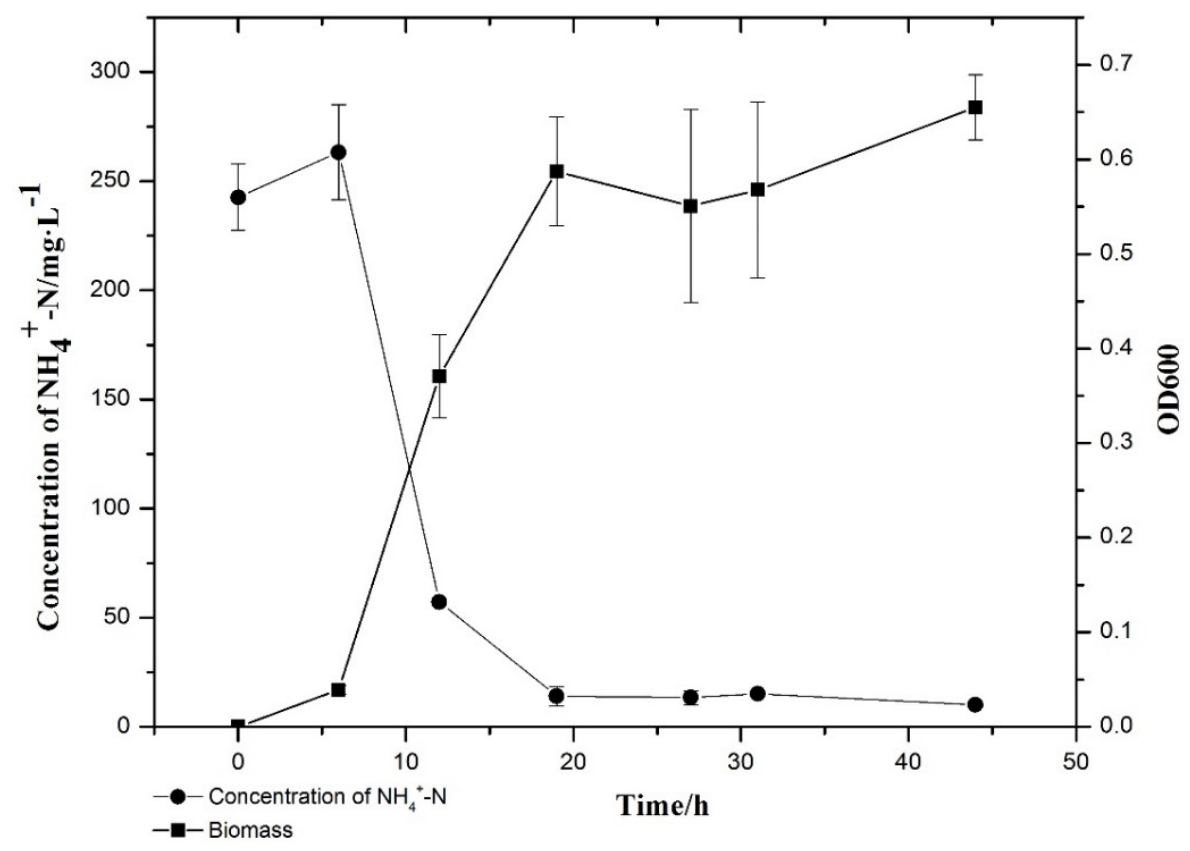

Figure 5. Degradation of ammonia nitrogen by Geotrichum sp. ZD 27.

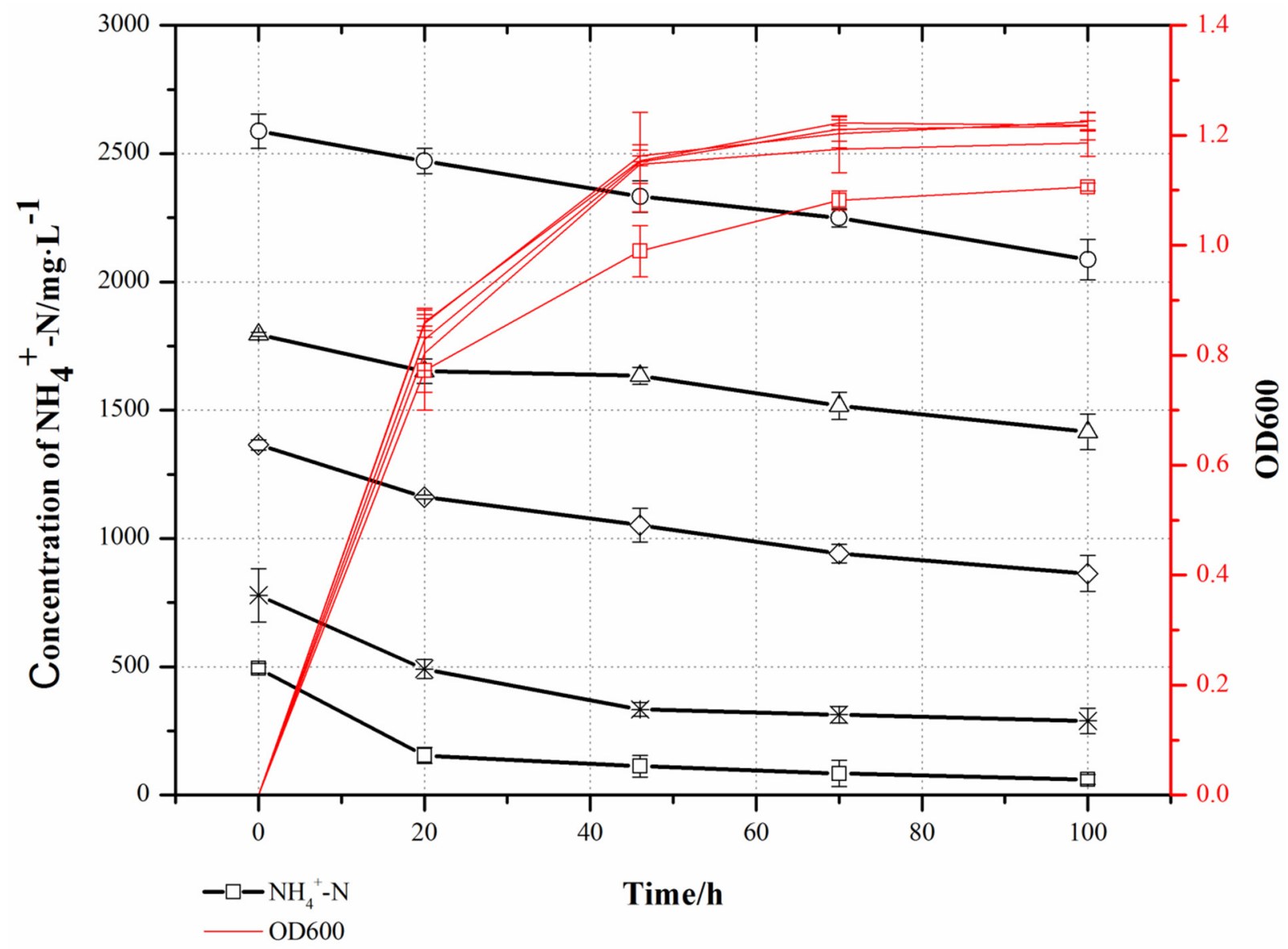

Figure 6. Degradation of ammonia nitrogen with different initial concentrations by Geotrichum sp. ZD 27. 
No. 27 fungus has a very strong ability to remove ammonia nitrogen and there is almost no $\mathrm{NO}_{3}{ }^{-}$residue (Supplementary Material Table S3). When the initial concentration of ammonia nitrogen is $242.66 \mathrm{mg} / \mathrm{L}$, the maximum degradation rate of ammonia nitrogen is $20.12 \mathrm{mg} / \mathrm{L} \cdot \mathrm{h}$ (the calculation methods refers to Yang et al. [45]), which is higher than that of fungi reported by Liu et al. [24]. In addition, No. 27 fungus is classified as a dimorphic fungus in the genus Geotrichum and its morphology is somewhat between bacteria and fungi. It forms short hyphae in liquid culture and reproduces in the form of arthrospores by hyphal rupture (Supplementary Material Figure S2). At the end of culture, the culture medium was stood, and the fungus settled naturally after about $3 \mathrm{~h}$ (Supplementary Material Figure S3). This feature allows omission of the step of centrifugal filtration in any industrial application, which offers the benefits of energy saving.

Table 3. Ammonium removal capability of the Geotrichum sp. at various nitrogen concentrations.

\begin{tabular}{cccc}
\hline Cultivation Time (h) & $\begin{array}{c}\text { Initial } \mathbf{~ N H}_{\mathbf{4}}{ }^{+}-\mathbf{N} \\
(\mathbf{m g} / \mathbf{L})\end{array}$ & $\begin{array}{c}\text { Final } \mathbf{~ N H}_{\mathbf{4}}{ }^{-}-\mathbf{N} \\
(\mathbf{m g} / \mathbf{L})\end{array}$ & $\begin{array}{c}\text { Removal Percentage } \\
\text { (\%) }\end{array}$ \\
\hline 20 & $242.66( \pm 15.28)$ & $14.10( \pm 4.40)$ & 94.42 \\
20 & $493.77( \pm 19.57)$ & $154.34( \pm 31.06)$ & 68.55 \\
46 & $778.54( \pm 103.49)$ & $333.59( \pm 27.06)$ & 56.91 \\
46 & $1364.61( \pm 20.18)$ & $1051.87( \pm 66.17)$ & 22.95 \\
70 & $1795.58( \pm 7.63)$ & $1517.16( \pm 53.39)$ & 15.50 \\
100 & $2587.59( \pm 66.64)$ & $2086.70( \pm 78.37)$ & 19.34 \\
\hline
\end{tabular}

\subsection{Optimisation Design of Degradation of No. 27 Fungus on Ammonia-Nitrogen Wastewater}

The rare earths were extracted through the adsorption by bacteria in the mother solution of mixed rare earths and the residual waste liquid contained a large amount of ammonia nitrogen with a concentration as high as $2200 \mathrm{mg} / \mathrm{L}$. The above experimental results pertaining to the degradation of ammonia nitrogen show that such a fungus could completely degrade ammonia nitrogen when the concentration of ammonia nitrogen was about $400 \mathrm{mg} / \mathrm{L}$, so the original waste liquid was diluted five-fold to reduce the ammonia nitrogen concentration to about $400 \mathrm{mg} / \mathrm{L}$. When diluting to about $400 \mathrm{mg} / \mathrm{L}$, there were almost no residual soil nutrients (such as $\mathrm{K}^{+}, \mathrm{Mg}^{2+}$, and $\mathrm{P}$ ) in the solution. A carbon source and inorganic salt were added to transform the waste liquid into the basal culture medium suitable for microbial growth. After optimization of the culture medium, ammonia nitrogen was degraded to the maximum extent. The COD, total nitrogen, total $\mathrm{P}$, ammonium nitrogen, and nitrate nitrogen were identified in the uniform experiment design and the determination results of each index are shown in Supplementary Material Table S3. SPSS was used to perform regression analysis on data, thus obtaining an equation $Y=-0.745081807 X_{1}-0.000330308 X_{2}{ }^{2}-0.001234486 X_{3}{ }^{2}+0.009908125 X_{1} X_{3}+$ $0.00134483 X_{2} X_{3}+84.9550\left(R^{2}=0.95\right)$, in which $X_{1}: \mathrm{C} / \mathrm{N} ; X_{2}: \mathrm{NH}_{4}{ }^{+}-\mathrm{N}(\mathrm{ppm})$ and $X_{3}: \mathrm{P}$ (ppm). $Y$ represents the percentage of removal of ammonia nitrogen. Theoretical calculation showed that, when $X_{1}=10, X_{2}=400$, and $X_{3}=190, Y_{\max }$ was $100 \%$. Under such conditions, No. 27 fungus was cultured for $3 \mathrm{~d}$ and the verification results are close to those calculated using the regression equation. At $C / N=10$, the initial concentration of ammonia nitrogen is $410 \mathrm{mg} / \mathrm{L}$, and that of the $\mathrm{P}$ source is $190 \mathrm{mg} / \mathrm{L}$, the percentage of removal of ammonia nitrogen is $88.67 \%$ after fermentation for $3 \mathrm{~d}$. The residual concentration of ammonia nitrogen in the waste liquid is $46.45 \mathrm{mg} / \mathrm{L}$, which is lower than the Indirect Emission Standard of Ammonia Nitrogen ( $50 \mathrm{mg} / \mathrm{L}$ ) of Pollutants for the Rare-earth Industry (GB 26451-2011).

In recent years, it is common to produce single cell protein through microbial fermentation with industrial wastes as raw materials, such as high-concentration fermentation wastewater, yellow serofluid, and waste molasses [46,47]. The fungus, Geotrichum, is a common strain used for producing single cell protein. In this study, the biomass of the No. 27 fungus fermented for $3 \mathrm{~d}$ in an optimized basal culture medium using ammonia nitrogen as a nitrogen source is $1.74 \pm 0.05 \mathrm{~g} / \mathrm{L}$ and the content of single cell protein accounts for 
$70.75 \%$ of the dry mass of the cells. Although the biomass of bacteria is low under such culturation conditions, the content of single cells is high, which has value in terms of the comprehensive utilization thereof.

\section{Conclusions}

The current extraction process of the ion adsorption-type rare-earth ore is facing elimination due to production of a large amount of ammonia-nitrogen wastewater. The need for a new, environmentally-friendly extraction process for ion adsorption-type rareearth ores is pressing. Bacillus sp. ZD 1 screened in this study has good adsorption effects on rare-earth $\mathrm{Y}^{3+}$ and can potentially be applied to extraction of rare-earths. Under an initial concentration of $\mathrm{Y}^{3+}$ of $1.13 \mathrm{mM}$, the adsorption capacity reached $428 \mu \mathrm{mol} / \mathrm{g}$ and $50 \mathrm{mg}$ of Bacillus sp. ZD 1 (converted to dry mass) can fully adsorb $\mathrm{Y}^{3+}$ in the mother solution of mixed rare-earths from leaching of the ore with ammonium sulphate solution.

The waste liquid after extraction of rare-earth ions through bacterial adsorption is transformed into the culture medium suitable for growth of fungi through dilution and addition of carbon source and inorganic salt. Thereafter, Geotrichum sp. ZD 27 was inoculated for heterotrophic nitrification and aerobic denitrification, thus removing ammonia nitrogen from wastewater. This causes the ammonia nitrogen concentration to be reduced from $400 \mathrm{mg} / \mathrm{L}$ to $46 \mathrm{mg} / \mathrm{L}$, which is lower than the Indirect Emission Standard of Pollutants for Rare-earth Industry (GB 26451-2011). Meanwhile, the resulting cells of Geotrichum sp. could be used to produce single cell protein, the content of which reached $70.75 \%$ (by dry mass) of cells. The research results show that bacterial adsorption and fungal denitrification have great application prospects in the integration of environmentally-friendly and efficient development of ion adsorption rare-earth ores and ecological restoration.

Supplementary Materials: The following are available online at https:/ / www.mdpi.com/article / 10.3390 /su13169460/s1. Table S1. The content of rare-earth elements in soil samples (Samples 1-5 is from the mined area, where the soil is high in quartz and grey-white in color. Samples 6-9 were obtained from an unmined area, where the soil is a red topsoil seen after removal of withered leaf matter). Table S2. The content of rare-earth elements in soil sample leaching liquor when using ammonium sulphate and the residual liquid after adsorption by bacterial cells. Table S3. Design of the uniform experiment and results of the determination of key indices. Figure S1. Transmission electron micrograph of Bacillus sp. ZD1 cells equilibrated with $1 \mathrm{mM} \mathrm{Y3+.} \mathrm{(a)} \mathrm{Precipitates} \mathrm{are} \mathrm{villous}$ deposits around the cell. Bar, $200 \mathrm{~nm}$. (b,c) show element maps of O (green) and Y (yellow). (d) Scans of the white rectangular box in a. Figure S2. Arthrospore of Geotrichum sp. ZD 27 under an optical microscope at $400 \times$ magnification. Figure S3. Natural settlement of the cultured Geotrichum sp. ZD 27 after standing for $3 \mathrm{~h}$.

Author Contributions: W.W.: Conceptualization, Methodology, Visualization, Validation, Formal analysis, Writing—original draft. Y.X.: Methodology, Execution of experiments. R.Y.: Conceptualization, Software, Formal analysis, Methodology. Z.Z.: Conceptualization, Writing-review \& editing, Funding acquisition. All authors have read and agreed to the published version of the manuscript.

Funding: National Natural Science Foundation of China (31760160), Youth Science and Technology Foundation of Jiangxi, China (20192BAB214002), and the Open Fund from the Key Laboratory of Protection and Utilization of Subtropical Plant Resources of Jiangxi (YRD201907).

Institutional Review Board Statement: Not applicable.

Informed Consent Statement: Not applicable.

Data Availability Statement: The data will be made available on request from the corresponding author.

Acknowledgments: We want to acknowledge Shunbao Ru for providing kjeldahl nitrogen determination instrument and acknowledge also Yao Zhang for help regarding the protein content determination.

Conflicts of Interest: The authors declare that they have no known competing financial interests or personal relationships that could have appeared to influence the work reported in this paper. 


\section{References}

1. Alonso, E.; Sherman, A.M.; Wallington, T.J.; Everson, M.P.; Field, F.R.; Roth, R.; Kirchain, R.E. Evaluating rare earth element availability: A case with revolutionary demand from clean technologies. Environ. Sci. Technol. 2012, 46, 3406-3614. [CrossRef]

2. Stone, R. As China's Rare Earth R\&D becomes ever more rarefied, others tremble. Science 2009, 325, 1336-1337. [PubMed]

3. Yang, G.M. Mineral Geology of China, Dossier of Jiangxi; Geology Press: Beijing, China, 2015.

4. Zhuang, W.Q.; Fitts, J.P.; Ajo-Franklin, C.M.; Maes, S.; Alvarez-Cohen, L.; Hennebel, T. Recovery of critical metals using biometallurgy. Curr. Opin. Biotechnol. 2015, 33, 327-335. [CrossRef] [PubMed]

5. US Department of Energy. Critical Materials Strategy. Available online: http://energy.gov/sites/prod/files/DOE_CMS2011_ FINAL_Full.pdf (accessed on 20 December 2011).

6. Zhu, H.L.; Yao, J. Study on the application of ammonia nitrogen wastewater treatment process in southern ionic rare earth mine area. Mod. Min. 2019, 602, 13-16.

7. Feng, A.J.; Xiao, X.; Ye, C.C.; Xu, X.M.; Zhu, Q.; Yuan, J.P.; Hong, Y.H.; Wang, J.H. Isolation and characterization of Burkholderia fungorum Gan-35 with the outstanding ammonia nitrogen-degrading ability from the tailings of rare-earth-element mines in southern Jiangxi, China. AMB Expr. 2017, 7, 140. [CrossRef]

8. Johnson, D.B. Biomining-biotechnologies for extracting and recovering metals from ores and waste materials. Curr. Opin. Biotech 2014, 30, 24-31. [CrossRef] [PubMed]

9. Brierley, C.L.; Brierley, J.A. Progress in bioleaching: Part B: Applications of microbial processes by the minerals industries. Appl. Microbiol. Biotechnol. 2013, 97, 7543-7552. [CrossRef]

10. Kucuker, M.A.; Kuchta, K. Biomining-biotechnological systems (bioleaching and biosorption) for the extraction and recovery of metals from secondary sources. In Proceedings of the 15th International Conference on Environmental Science and Technology, Rhodes, Greece, 31 August-2 September 2017.

11. Cheng, Y.; Zhang, L.; Bian, X.; Zuo, H.; Dong, H. Adsorption and mineralization of REE-lanthanum onto bacterial cell surface. Environ. Sci. Pollut. Res. Int. 2017, 25, 22334-22339. [CrossRef]

12. Bonificio, W.D.; Clarke, D.R. Rare-earth separation using bacteria. Environ. Sci. Technol. Lett. 2016, 3, 180-184. [CrossRef]

13. Tsuruta, T. Accumulation of rare earth elements in various microorganisms. J. Rare Earth 2007, 25, 526-532. [CrossRef]

14. Markai, S.; Andre's, Y.; Montavon, G.; Grambow, B. Study of the interaction between europium (III) and Bacillus subtilis: Fixation sites, biosorption modeling and reversibility. J. Colloid Interf. Sci. 2003, 262, 351-361. [CrossRef]

15. Wang, W.; Xu, C.; Jin, Y.; Zhang, Z.; Zhu, D. The accumulation of rare-earth yttrium ions by Penicillium sp. ZD28. AMB Express 2020, 10, 25. [CrossRef]

16. Gupta, V.K.; Sadegh, H.; Yari, M.; Ghoshekandi, R.S.; Maazinejad, B.; Chahardori, M. Removal of ammonium ions from wastewater: A short review in development of efficient methods. Glob. J. Environ. Sci. Manag. 2015, 1, 149-158.

17. Breisha, G.Z.; Winter, J. Bio-removal of nitrogen from wastewaters-a review. Nat. Sci. 2010, 8, $210-228$.

18. Schmidt, I.; Sliekers, O.; Schmid, M.; Bock, E.; Fuerst, J.; Kuenen, J.G.; Jetten, M.S.M.; Strous, M. New concepts of microbial treatment processes for the nitrogen removal in wastewater. FEMS Microbiol. Rev. 2003, 27, 481-492. [CrossRef]

19. Chen, Q.; Ni, J.R. Ammonium removal by Agrobacterium sp. LAD9 capable of heterotrophic nitrification- aerobic denitrification. J. Biosci. Bioeng. 2012, 113, 619-623. [CrossRef] [PubMed]

20. Laughlin, R.J.; Rütting, T.; Müller, C.; Watson, C.J.; Stevens, R.J. Effect of acetate on soil respiration, $\mathrm{N}_{2} \mathrm{O}$ emissions and gross $\mathrm{N}$ transformations related to fungi and bacteria in a grassland soil. Appl. Soil Ecol. 2009, 42, 25-30. [CrossRef]

21. Laughlin, R.J.; Stevens, R.J.; Müller, C.; Watson, C.J. Evidence that fungi can oxidize $\mathrm{NH}_{4}{ }^{+}$to $\mathrm{NO}_{3}{ }^{-}$in a grassland soil. Eur. J. Soil Sci. 2008, 59, 285-291. [CrossRef]

22. Chi, R.A.; Tian, J. Weathered Crust Elution-Deposited Rare Earth Ores; Nova Science Publishers: New York, NY, USA, 2008.

23. Hogendoorn, C.; Roszczenko-Jasińska, P.; Martinez-Gomez, N.C.; Graaff, J.; Grassl, P.; Pol, A.; Op den Camp, H.; Daumann, L. Facile arsenazo iii-based assay for monitoring rare earth element depletion from cultivation media for methanotrophic and methylotrophic bacteria. Appl. Environ. Microbiol. 2018, 84, e02887-17. [CrossRef]

24. Liu, Z.; Liu, G.; Cai, H.; Shi, P.; Chang, W.; Zhang, S.; Zheng, A.; Xie, Q.; Ma, J. Paecilomyces variotii: A fungus capable of removing ammonia nitrogen and inhibiting ammonia emission from manure. PLoS ONE 2016, 11, e0158089. [CrossRef] [PubMed]

25. Kelly, S.D.; Kemner, K.M.; Fein, J.B.; Fowle, D.A.; Boyanov, M.I.; Bunker, B.A.; Yee, N. X-ray absorption fine structure determination of pH-dependent U-bacterial cell wall interactions. Geochim. Cosmochim. Acta 2002, 66, 3855-3871. [CrossRef]

26. Boyanov, M.I.; Kelly, S.D.; Kemner, K.M.; Bunker, B.A.; Fein, J.B.; Fowle, D.A. Adsorption of cadmium to Bacillus subtilis bacterial cell walls: A pH-dependent X-ray absorption fine structure spectroscopy study. Geochim. Cosmochim. Acta 2003, 67, 3299-3312. [CrossRef]

27. Mullen, M.D.; Wolf, D.C.; Ferris, F.G.; Beveridge, T.J.; Flemming, C.A.; Bailey, G.W. Bacterial sorption of heavy metals. Appl. Environ. Microbiol. 1989, 55, 3143-3149. [CrossRef] [PubMed]

28. Texier, A.C.; Andrès, Y.; Cloirec, P.L. Selective biosorption of lanthanide (La, Eu, Yb) ions by Pseudomonas aeruginosa. Environ. Sci. Technol. 1999, 33, 489-495. [CrossRef]

29. Zhao, C.M.; Wilkinson, K.J. Biotic ligand model does not predict the bioavailability of rare earth elements in the presence of organic ligands. Environ. Sci. Technol. 2015, 49, 2207-2214. [CrossRef]

30. Takahashi, Y.; Kondo, K.; Miyaji, A.; Watanabe, Y.; Fan, Q.; Honma, T.; Tanaka, K. Recovery and separation of rare earth elements using salmon milt. PLoS ONE 2014, 9, e114858. [CrossRef] 
31. Mao, J.; Won, S.W.; Vijayaraghavan, K.; Yun, Y.S. Surface modification of Corynebacterium glutamicum for enhanced reactive red 4 biosorption. Bioresour. Technol. 2009, 100, 1463. [CrossRef]

32. Li, D.; Li, R.Y.; Ding, Z.X.; Ruan, X.F.; Luo, J.; Chen, J.Y.; Zheng, J.; Tang, J.X. Discovery of a novel native bacterium of Providencia sp. with high biosorption and oxidation ability of manganese for bioleaching of heavy metal contaminated soils. Chemosphere 2020, 241, 125039.

33. Kumar, V.; Singh, S.; Singh, G.; Dwivedi, S.K. Exploring the cadmium tolerance and removal capability of a filamentous fungus Fusarium solani. Geomicrobiol. J. 2019, 36, 782-791. [CrossRef]

34. Romero-Gonzalez, M.E.; Williams, C.J.; Gardiner, P.H.E. Study of the mechanisms of cadmium biosorption by dealginated seaweed waste. Environ. Sci. Technol. 2001, 35, 3025-3030. [CrossRef]

35. Chen, C.; Wang, J. Influence of metal ionic characteristics on their biosorption capacity by Saccharomyces cerevisiae. Appl. Microbiol. Biotechnol. 2007, 74, 911-917. [CrossRef]

36. Özdemir, S.; Kilinc, E.; Poli, A.; Nicolaus, B.; Güven, K. Biosorption of Cd, Cu, Ni, Mn and Zn from aqueous solutions by thermophilic bacteria, Geobacillus toebii sub. sp. decanicus and Geobacillus thermoleovorans sub. sp. stromboliensis: Equilibrium, kinetic and thermodynamic studies. Chem. Eng. J. 2009, 152, 195-206.

37. Aller, A.J.; Castro, M.A. Live bacterial cells as analytical tools for speciation analysis: Hypothetical or practical? Trac-Trends Anal. Chem. 2006, 25, 887-898. [CrossRef]

38. Li, J.; Liu, Y.L.; Zhang, L.M.; He, J.Z. Sorption mechanism and distribution of cadmium by different microbial species. J. Environ. Manag. 2019, 237, 552-559. [CrossRef]

39. Zhang, J.H.; Li, Q.; Zeng, Y.F.; Zhang, J.; Lu, G.N.; Dang, Z.; Guo, C.L. Bioaccumulation and distribution of cadmium by Burkholderia cepacia GYP1 under oligotrophic condition and mechanism analysis at proteome level. Ecotox. Environ. Saf. 2019, 176, 162-169. [CrossRef] [PubMed]

40. Lee, J.; Pandey, B. Bio-processing of solid wastes and secondary resources for metal extraction-a review. Waste Manag. 2012, 32, 3-18. [CrossRef]

41. Bharadwaj, A.; Ting, Y. From biomining of mineral ores to bio urban mining of industrial waste. In Proceedings of the Environmental Technology Management Conference 4th ETMC, Bandung, Indonesia, 3-4 November 2011.

42. Yang, X.; Wang, S.; Zhou, L. Effect of carbon source, $\mathrm{C} / \mathrm{N}$ ratio, nitrate and dissolved oxygen concentration on nitrite and ammonium production from denitrification process by Pseudomonas stutzeri D6. Bioresour. Technol. 2012, 104, 65-72. [CrossRef] [PubMed]

43. Joo, H.S.; Hirai, M.; Shoda, M. Characteristics of ammonium removal by heterotrophic nitrification-aerobic denitrification by Alcaligenes faecalis No. 4. J. Biosci. Bioeng. 2005, 100, 184-191. [CrossRef]

44. Lu, Y.K.; Niu, F.L.; Liu, Y.X.; Zhang, L. Isolation and characteristic of a new heterotrophic nitrification fungus. J. Taiyuan Univ. Technol. 2015, 46, 129-133.

45. Yang, L.; Chen, N.; Ren, Y.; Cui, S.; Wang, X.; Xiao, Q.; Guo, L. Simultaneous nitrogen and phosphorus removal and kinetics by the heterotrophic nitrifying bacterium Acinetobacter junii NP1. Environ. Sci. 2019, 40, 3713-3720.

46. Gao, J.; He, T.; Cheng, X.; Feng, L.; Zhang, L. Performance of the combined EGSB-MBR reactor treating fermentation wastewater. China Environ. Sci. 2015, 35, 1416-1422.

47. Shen, P.; Han, F.; Su, S.; Zhang, J.; Chen, Z.; Li, J.; Gan, J.; Feng, B.; Wu, B. Using pig manure to promote fermentation of sugarcane molasses alcohol wastewater and its effects on microbial community structure. Bioresour. Technol. 2014, 155, 323-329. [CrossRef] 